1 dollar). The report is by the chairman, Prof. W. H. Twenhofel, who contributes a general introduction, and various committee members and others, who are responsible for many valuable records of original research and abstracts of literature on the accessory minerals of igneous and sedimentary rocks. Special attention deserves to be given to the paper on the classification and terminology of the pyroclastic rocks by C. K. Wentworth and Howel Williams. The Bulletin also includes papers on recent advances in the study of peat; recent marine sediments; settling of bentonite in water ; relation of the buffer mechanism of sea water to the solubility of calcium carbonate; modern marine sediments in California; bacterial and chemical factors in lime deposition at Tortugas, Florida ; varved sediments ; chert and flint, concretions, and cone-in-cone; abrasional work of river ice and of glaciers; ground water hydrology in its bearing on sedimentation; rôle of micro-organisms in sediments; accessory minerals of crystalline rocks; and glacial sediments. In addition, there are summaries of work on sedimentation carried out at Stanford University, and also of recent work by German and British investigators; and abstracts of the literature on accessory minerals of igneous rocks and of sedimentary rocks.

\section{Developments in Market Gardening}

THE report of the recent conference on "Recent Developments in Market Gardening" held at Rothamsted contains a great deal of information which is not readily available in a collected form. Two of the classical market garden areas, the Bedfordshire early potato and brussels sprouts district and the equally well-known spring cabbage, brussels sprouts and fruit area of Evesham are treated in detail from the point of view of the practical grower, and the subject is also considered from the point of view of the canner, whose part in the industry is becoming increasingly important. In recent years market gardeners have found their province invaded by large-scale farmers, who have in part substituted vegetable growing for the less profitable crops of their ordinary rotation. These men, whose methods form the subject of one of the papers, have several advantages not possessed by the smaller cultivators; plentiful animal manures, large-scale mechanical methods, and a possibility of converting unsaleable surplus into live stock products. The reply of the genuine market gardener has been to move towards greater intensification, and to retire into districts as yet inaccessible to large-scale methods. The conference as a whole leaves the impression that abundant production of market garden crops is relatively easy to secure. It can in fact be an embarrassment, and every additional outlet whether by preservation, more economical distribution, or the education of the public taste, needs careful investigation. Copies of the report, price $2 s$., can be obtained from the Secretary, Rothamsted Experimental Station, Harpenden, Herts.

\section{Institute of Industrial Administration}

IN a pamphlet recently issued by the Institute of Industrial Administration, 47 King William Street,
E.C.4, outlining its objects and examinations, it is stated that management in industry is essentially the exercise of administrative function and involves the control and co-ordination of the technical functions. The operation of the administrative function does nut vary greatly from one industry to another despite differences in the application of some of the technical functions, especially that of production. It is admitted that personality is a highly significant factor in industrial administration but training serves both to develop and inform personality. To the average individual upon whom industry has mainly to rely, training may make all the difference in his efficiency, to his own advantage and that of the nation. In preparing a revised syllabus of examinations, the Institute has endeavoured to collate the principles and practice bearing on the functional aspects of industrial administration. The scheme consists of three stages-fundamentals, intermediate and final - the first of which presents in elementary form a general idea of how an industrial undertaking is conducted and its relation to external affairs. In the intermediate and final stages the subjects of the fundamental stage are extended and amplified.

\section{Physics at Harvard}

VoL. 21 of Contributions from the Physical Laboratories of Harvard University consists of separate copies of the papers by members of the staff and other research workers which have appeared in the Physical Review, the Proceedings of the National Academy of Sciences and of the American Academy and other periodicals during 1930-31. There are forty of them, which differ considerably in type and area of the letterpress, but are all cut to pages $9 \frac{1}{4}$ in. $\times 6 \frac{3}{4}$ in. Their subjects extend over almost every branch of physics and they testify to the catholicity and quality of the research work done at Harvard. The completion of the new research laboratory and the improvement of the Jefferson Laboratory during the period covered by the volume afford a suitable opportunity for a 47-page illustrated description of the present buildings and equipment, and a short history of their foundation and of the work done in them, and in the Cruft Laboratory. Nearly 130 men have carried on research in the laboratories during the last thirty years and many of them now fill chairs of physics in American universities.

\section{Mining Facilities in South Australia}

According to the annual report of the Director of Mines and Government Geologist of South Australia for 1931, an amending act was passed during the year concerning principally mining upon lands, beneath which mineral substances had been alienated prior to the adoption of the principle of reservation of such substances. The act protects land-owners, but under certain conditions allows prospectors to enter such lands under reasonable conditions; the responsibility for seeing that such an authority is not given to an undesirable character is placed upon the Warden. 